\title{
Using Gis AND REMote SENSING TECHNIQUES FOR SOLAR HOTSPOTS INSTALLATION IN THIRU NAGAR, Dindigul DisTrict
}

\author{
N.D.Mani ${ }^{1}$ and Penmaya Ningshen ${ }^{2}$ \\ ${ }^{1}$ Professor, Department of Rural Development, The Gandhigram Rural Institute - \\ Deemed University, Gandhigram - 624302, Tamil Nadu, India \\ ${ }^{2}$ II M.Sc Geoinformatics, Centre for Geoinformatics, The Gandhigram Rural Institute - \\ Deemed University, Gandhigram - 624302, Tamil Nadu, India
}

\begin{abstract}
Solar energy has been widely tapped around the world replacing conventional non-renewable energy. Currently, one of the most challenging problems is to increase the quantity of energy tagged from solar energy. Before installing solar panels, assessing where solar panels should be placed can significantly benefit panel performance. This study aims to conduct a site selection analysis for solar panel installation using Geographical Information Systems (GIS). The focus of the analysis is on building rooftop PVC panel installation.
\end{abstract}

In this study, Google Earth images were used to digitize the rooftop that is potential for solar PVC panel and derive the areas using ArcGIS software.

\section{KEYWORDS}

Solar energy, GIS, Remote Sensing, Renewable energy.

\section{INTRODUCTION}

In recent times, the nature and magnitude of global energy demands have increased in an unprecedented manner, especially with today's rapid population growth and modernization. Since the Industrial Revolution from the 18thto the 19th century, conventional fossil fuels have been largely consumed and consequently, various greenhouse gases (e.g., $\mathrm{Co} 2, \mathrm{CH} 4$, etc.) have been emitted into the atmosphere. This has led to an abnormal increase in the earth's average atmospheric temperature and other environmental concerns. Renewable or green forms of energy have been proposed as substitute for conventional resource, and are now generally believed to be capable of meeting much of the growing energy demand.

In India, sources of renewable electricity (i.e., water, wind, solar, geothermal and biomass) produced as on 31.03.14 is estimated at $147615 \mathrm{MW}$. This includes wind power potential of 102772 MW (69.6\%), SHP (Small-Hydro Power) potential of 19749 MW (13.38\%), Biomass power potential of 17,538 MW (11.88\%) and 5000 MW (3.39\%) from bagasse-based cogeneration in sugar mills (Energy statistics 2015). Among the renewable energy sources, solar energy is unique in that it can provide a local source of electricity for people living in rural areas which are not having direct access to the electric grid. 
Solar energy is transmitted to the earth in the form of electromagnetic radiation, which is comprised of photons. The amount of irradiance reaching a location on the earth's surface over a specific time period varies depending on global, local, spatial, temporal and meteorological factors. Generally, large quantities of solar energy manifest in diverse forms when reaching the earth, such as direct sunlight for photosynthesisplant, heated air masses causing wind, and evaporation of the oceans, which result in rain that in turn, supplies water to rivers and provides energy to produce hydropower. Achieving an accurate estimation of daily, monthly or yearly global solar radiation reaching the earth's surface is of great importance when developing solar energy resources, especially when determining the optimal location for placing photovoltaic panels. Identifying appropriate sites for solar panel placement is beneficial not only ecologically by considering environmentally sensitive areas and land accessibility, but also economically by analyzing energy production potential, existing transmission system, and the solar power market.

\section{REVIEW OF LITERATURE}

\subsection{ENERgy Policy OF INDiA}

The energy policy of India is largely defined by the country's burgeoning energy deficit and increased focus on developing alternative sources of energy, particularly nuclear, solar and wind energy. The energy consumption in India is the fourth biggest after China, USA and Russia. In 2009-10, the country imported 159.26 million tons of crude oil which amounts to $80 \%$ of its domestic crude oil consumption and $31 \%$ of the country's total imports are oil imports. The growth of electricity generation in India has been hindered by domestic coal shortages and as a consequence, India's coal imports for electricity generation increased by $18 \%$ in 2010.The total primary energy consumption from crude oil $(29.45 \%)$, natural gas $(7.7 \%)$, coal $(54.5 \%)$, nuclear energy (1.26\%), hydro-electricity $(5.0 \%)$, wind power, biomass electricity and solar power is 595 Mtoe in the year 2013. In the year 2013, India's net imports are nearly 144.3 million tons of crude oil, 16 Mtoe of LNG and 95 Mtoe coal totaling to 255.3 Mtoe of primary energy, which is equal to $42.9 \%$ of total primary energy consumption. About $70 \%$ of India's electricity generation capacity is from fossil fuels. Given India's growing energy demands and limited domestic fossil fuel reserves, the country has ambitious plans to expand its renewable and nuclear power resources. India also envisages to increase the contribution of nuclear power to overall electricity generationcapacity from $4.2 \%$ to $9 \%$ within 25 years. The country has five nuclear reactors under construction (third highest in the world) and plans to construct 18 additional nuclear reactors (second highest in the world) by 2025. India is largely dependent on fossil fuel imports to meet its energy demands - by 2030, India's dependence on energy imports is expected to exceed 53\% of the country's total energy consumption. Due to rapid economic expansion, India has one of the world's fastest growing energy markets and is expected to be the second largest contributor to the increase in global energy demand by 2035 , accounting for $18 \%$ of the rise in global energy consumption.

\subsection{SOLAR ENERGY AND GROWTH OF PV IN INDia}

India's solar energy insolation is about 5,000 T kWh per year (i.e. 600 TW), far more than its current total primary energy consumption. India's long term solar potential could be unparalleled in the world because it has the ideal combination of both high solar insolation and a big potential consumer base density. With a major section of its citizens still surviving off grid, because India's grid system is considerably underdeveloped. Availability of cheap solar energy can bring electricity to people, and bypass the need of installation of expensive grid lines. Also a major factor influencing a region's energy intensity is the cost of energy consumed for temperature control. Since cooling load requirements are roughly in phase with the sun's intensity, cooling 
from intense solar radiation could make perfect energy economic sense in the subcontinent, whenever the required technology becomes competitively cheaper. Installation of solar power plants require nearly 2.4 hectares (6 acres) of land per MW capacity which is similar to coal fired power plants when life cycle coal mining, consumptive water storage and ash disposal areas are also accounted and hydro power plants when submergence area of water reservoir is also accounted. 1.33 million MW capacity solar plants can be installed in India on its 1\% land (32,000 square $\mathrm{km}$ ). There are vast tracts of land suitable for tapping solar power in all parts of India exceeding $8 \%$ of its total area which are unproductive barren and devoid of vegetation. This part of waste lands $(32,000$ square $\mathrm{km})$ when installed with solar power plants can produce 2000 billion $\mathrm{kWh}$ of electricity (two times the total generation in the year 2013-14) with land productivity/yield of 1.5 million Rs/ acre (Rs. $6 / \mathrm{kWh}$ price) which is at par with many industrial areas and many times more than the best productive irrigated agriculture lands. Moreover, these solar power units are not dependent on supply of any raw material and are self-productive. There is unlimited scope for solar electricity to replace all fossil fuel energy requirements (natural gas, coal, lignite and crude oil) if all the marginally productive lands are occupied by solar power plants in future. The solar power potential of India can meet perennially to cater per capita energy consumption at par with USA and Japan for the peak population in its demographic transition.

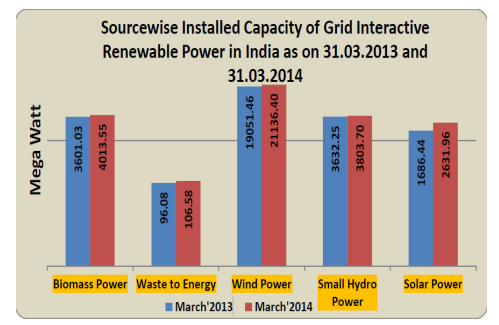

Figure 1: Source Wise Installed Capacity of Grid Interactive Renewable Energy 2013-14

The above figure 1 shows that wind energy is the highest capacity of renewable energy followed by biomass energy but among all these energy capacity grid, solar is the fastest growing capacity for renewable energy as on the data compared with 2013 and 2014.

Table 1: Source wise Installed Capacity of Grid Interactive Renewable energy in India as on 2013-2014

\begin{tabular}{|c|c|c|c|c|c|c|}
\hline \multirow{2}{*}{$\begin{array}{l}\text { SI. } \\
\text { No. }\end{array}$} & \multirow{2}{*}{$\begin{array}{l}\text { Types } \\
\text { of } \\
\text { energy }\end{array}$} & \multicolumn{2}{|c|}{ Years } & \multicolumn{2}{|c|}{ Distribution (\%) } & \multirow{2}{*}{$\begin{array}{l}\text { Grow } \\
\text { th* } \\
\text { Rate } \\
(2012 \\
-13 \text { to } \\
2013- \\
14)\end{array}$} \\
\hline & & 2013 & 2014 & 2013 & 2014 & \\
\hline 1 & $\begin{array}{l}\text { Biomass } \\
\text { Power }\end{array}$ & 3601.03 & 4013.55 & 12.83 & 12.66 & \multirow{5}{*}{12.92} \\
\hline 2 & $\begin{array}{l}\text { Waste to } \\
\text { Energy }\end{array}$ & 96.08 & 106.58 & 0.34 & 0.34 & \\
\hline 3 & $\begin{array}{l}\text { Wind } \\
\text { Power }\end{array}$ & 19051.46 & 21136.40 & 67.88 & 66.69 & \\
\hline 4 & $\begin{array}{l}\text { Small } \\
\text { Hydro } \\
\text { Power }\end{array}$ & 3632.25 & 3803.70 & 12.94 & 12.00 & \\
\hline 5 & $\begin{array}{l}\text { Solar } \\
\text { Power }\end{array}$ & 1686.44 & 2631.96 & 6.01 & 8.30 & \\
\hline
\end{tabular}




\subsection{Photovoltaic Systems}

PV systems consist of PV solar panels installed on rooftops or mounted on posts in the ground. These systems operate by sunlight/photons striking a PV cell, and an electric current being produced by stimulating electrons (negative charges) in a layer in the cell designed to give up electrons easily. The existing electric field in the solar cell pulls these electrons to another layer. By connecting the cell to an external load, this movement of charges can then be used to power the load (EPA and NREL, 2013). Usually, a PV system is comprised of a series of collector panels, batteries wires, and devices that convert electricity into its Alternating Current (AC) form that can be used for powering household appliances and lights.

PV technology has been shown to offer numerous advantages over conventional energy converters, which are summarized in Table 2.2. First, PV cells are solid-state devices with no moving parts; therefore, nearly no maintenance is required for their simple and robust design. Second, PV panels do not require an additional energy source, such as fuel to operate, meaning that less transport is required. Since the demand for transportation of fuel and technicians is low, PV technology is exceptionally useful in remote areas. These systems also have the uniqueness of being totally scalable, giving the possibility of expanding the system, once demand increases and enough space is available. Furthermore, the life cycle cost is generally lower than other conventional lighting sources in developing regions and remote areas. Therefore, PV power is a sustainable energy alternative that offers substantial advantages over conventional sources of energy.

Table 2: The Advantages and Disadvantages of PV Technology

\begin{tabular}{|c|c|c|}
\hline SI.No. & Advantages & Disadvantages \\
\hline 1 & Less maintenance required & Large upfront costs \\
\hline 2 & $\begin{array}{l}\text { No need for external operating } \\
\text { support }\end{array}$ & Maintenance issues for battery systems \\
\hline 3 & Ideal for remote areas & Potential construction contamination \\
\hline 4 & $\begin{array}{l}\text { Less life cycle cost and } \\
\text { sustainable and clean }\end{array}$ & $\begin{array}{l}\text { Cannot place in shade, need sunlight } \\
\text { and generate power only day time }\end{array}$ \\
\hline
\end{tabular}

Nevertheless, different PV systems also have various drawbacks (summarized in Table 2). The service cost and lifetime of off-grid and on-grid PV systems are diverse. In particular, batteries needed in an off-grid system are a recurring problem. The batteries themselves can be expensive, inefficient and not environmentally friendly. For example, electrolyte in lead batteries without extra protection may evaporate in hot climate. Faulty usage or maintenance may also lead to unnecessarily shortening of a battery's lifetime. In remote areas, there is a risk of batteries ending up in the backyard, where they may pollute the ambient environment. Therefore, the best way of making use of a PV system is to utilize the electricity immediately when it is generated.

In addition, physical conditions of the installation location may further impact on the service cost and lifetime of the system. For example, operation and maintenance may account for half of the service cost in areas with hot and humid conditions. Another potential drawback is the construction process of a PV system may lead to environmental damage to the surrounding landscape. Finally, PV arrays may cause visualization or aesthetics issues to the local residents. 


\subsubsection{STAND-ALONE SYSTEM}

PV systems can be used for a wide variety of applications, from small stand-alone systems to large utility grid-connected systems. Stand-alone systems (or off-grid systems) are usually used in remote areas that are not easily accessible to an electric grid. Energy produced by such systems is normally stored in batteries. Typically, a stand-alone system consists of a PV module or modules, a charge controller, and batteries (shown in Figure 2). The charge controller regulates the power from PV modules and delivers Direct Current (DC) electricity for storage. An inverter is included to convert $\mathrm{DC}$ electricity to $\mathrm{AC}$ form that is required by normal appliances. This type of application provides cost-effective, modest levels of power for fans, lighting, communication, water pumping, and so on.

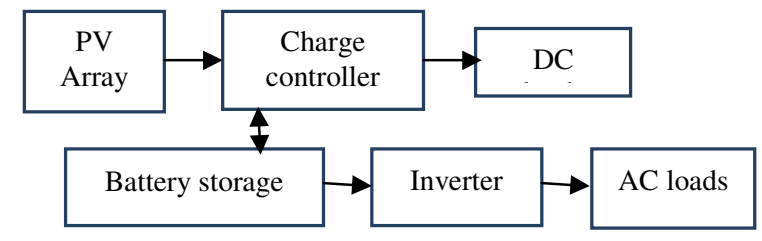

Figure 2: Schematic Chart of a Stand-alone PV Application

Since solar power can be generated only during the daytime when sunshine is available, battery storage is a significant component for this type of system, especially during the winter season. Hence, in places where winter allow for very limited hours of sunshine, the stand-alone system is bridged with a hybrid system.

\subsubsection{GRID CONNECTED SYSTEM}

The grid-connected systems (or grid-tied systems) are designed for decentralized applications. During the daytime, DC electricity generated by the system is converted to AC by the inverter and fed into a power distribution system. The electricity can either be utilized immediately or be transmitted and sold to an electricity supplier. In the evening, when solar power cannot be generated, power can be bought back from the network. This system does not include battery storage, since the grid acts as an energy storage system. A schematic diagram of a grid-connected PV system is shown in Figure 3.

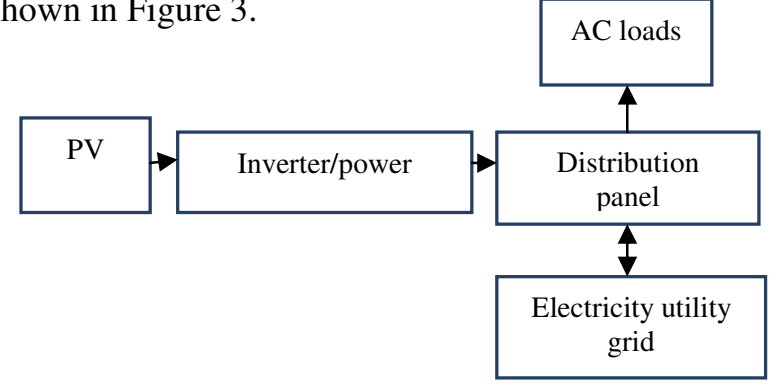

Figure 3: Grid-Connected System

In effect, the cost of bringing utility power via transmission and distribution lines to other areas connecting to the grid is significant, especially for small household electrical loads and villages located at great distances over difficult terrain from the transmission grid. In addition, the cost of grid extension can be prohibitive, especially for a gully, mountain, or other difficult terrain conditions. 


\subsection{Statement of the Problem}

In order to identify potential sites for solar panel installation, availability of solar radiation should be considered first. Based on different data sources, such as weather station data and elevation data, solar radiation can be estimated using different approaches. For example, solar radiation can be obtained by weather station surveillance, which measures irradiance for a specific location. Solar radiation data are gathered in the form of dispersed observation points, and interpolation techniques can be used to estimate unknown radiation data in intervening areas. Multivariate statistical methods are another approach for estimating solar radiation and are based on multiple variables, such as latitude and sunshine ratio. Additionally, Light Detection and Ranging (LiDAR) data or high-resolution Digital Elevation Model (DEM) data have been implemented to estimate radiation at the small scale or regional level, typically for a subdivision in an urban area or individual fields. The thermal band of optical imagery with detected surface temperature information can also be used to calculate solar irradiation. This study will focus on using topographic information derived from Google earth images.

Locating potential rooftop for PV panels should also take into account other factors based on the scale and type of installation involved. More specifically, for rooftop solar panel installation, shadow effects due to surrounding obstacles and roof structure are important factors to be considered. In some regions with abundant dust, effects of dust accumulation on the performance of solar panels are important.

\subsection{AIM AND OBJECTIVES}

The main aim of the present study is to demonstrate the potential benefits of applying spatial analytical techniques to remote sensing data for determining the optimal sites for solar panel installation at rooftop. The analysis considers solar panel installation on building roofs and determination is primarily based on the spatial variation of incoming solar radiation on a building rooftop surface.

The main objectives of the present study are to:

i. identify the rooftop and select the area that is potential for solar installation

ii. calculate the solar potential area

iii. calculate the solar radiation of the region

iv. calculate amount of energy generated from the solar panel

v. find out the power generation from each rooftop.

\section{MeTHODOLOGY}

To develop a process for solar panel installation a simple method were use base on the condition of the study area. First, the rooftops were digitized and select the area that has potential for panel solar installation considering the shade, shadow and type of rooftop. Data preprocessing of solar radiation estimation, was conducted. Monthly- and yearly-accumulated solar radiations were collected from Internet. Details about the adopted methodology for this study are further described in the following sections.

\subsection{Flow CHART}

The methodology used in of this study has been presented in this flow chart. The rooftop area that has potential for the solar installation is digitized and area was found out. By multiplying the solar potential area and average of solar radiation, gave each rooftop that produces solar energy in $\mathrm{kWh}$ per day. 


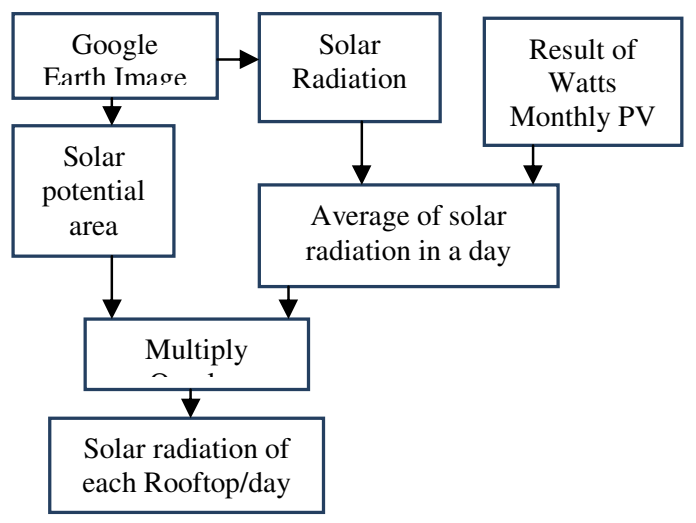

Figure 4: Flow Chart

\subsection{STUDY AREA}

Area selected of this study is Thirunagar, Chinnalapatti Dindigul District,Tamil Nadu. It is located between 77o.92'E \& 770.92'E and $100.27^{\prime} \mathrm{N} \& 10 \mathrm{o.27}$ ' $\mathrm{N}$. For the rooftop analysis, there are 53 building which is shown below in figure 3.1. The selection of rooftop for solar installation is based on the area, where it receives maximum sunlight considering the shade, shadow and type of the rooftop.

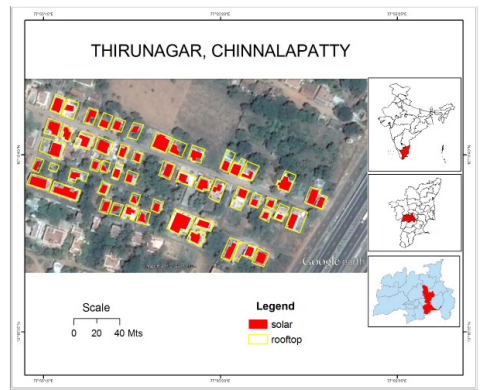

Map 1: Rooftop Potential for Solar Installation

\subsection{DATA AND SOFTWARE USED}

Data used in the present study are Google Earth images downloaded using El-Shayal Smart Web on Line Software with a resolution of $2.5 \mathrm{~m}$ of 29th Sept 2015 and data derived from online PVWATTS calculator result from the website of NREL (National Renewable Energy Laboratory).

The two main software used in this study are;

i. ArcGIS : this software are used to digitizing the rooftop, finding out the area of the rooftop and map layout.

ii. ERDAS Imagine : used to mosaic the downloaded Google Images of different tilts.

\subsection{LiMitATION OF THE STUDY}


There was no LiDAR data available for the study area, most of the studies and research for solar has been carried out using LiDAR data, because of this reason a limited criteria was considered in this study.

\section{RESULTS AND DISCUSSION}

\subsection{Solar RAdiation MAPS}

The solar radiation data were processed in ArcGIS using the Google Earth images of the area. By using the level of solar radiation, the area of solar radiation, can be calculated which is shown in figure 4.1 .

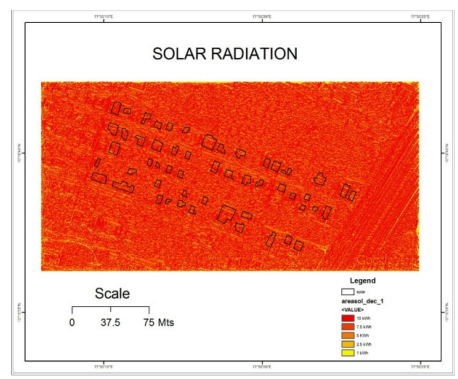

Map 2: Solar Radiation

According to the above Map-4.1 it is found out that the radiation of solar energy of the rooftop is 7.5 Kwh in all the rooftop but this exact value cannot be used because there is some energy lose, therefore $5.6 \mathrm{kWh}$ is taken as an average value of energy generated.

\subsection{MONTHLY SOLAR RAdiation}

The solar radiation data were collected from the website of NREL (National Renewable Energy Laboratory) by typing the address of the study area, in the given link it automatically generates the information (http://pvwatts.nrel.gov/India/pvwatts.php). The result of the output were given below.

Table 3. Result of PV WATTS Calculator (6,013 kWh per Year)

\begin{tabular}{|l|r|r|r|}
\hline Month & $\begin{array}{l}\text { Solar Radiation } \\
(\mathbf{k W h} / \mathbf{~ m 2 ~ / ~ d a y ~})\end{array}$ & $\begin{array}{l}\text { AC Energy } \\
(\mathbf{~ k W h ~})\end{array}$ & $\begin{array}{l}\text { Energy } \\
\text { Value } \\
\text { in Rs. }\end{array}$ \\
\hline January & 6.27 & 570 & 2,069 \\
\hline February & 7.18 & 572 & 2,077 \\
\hline March & 6.57 & 571 & 2,074 \\
\hline April & 5.69 & 481 & 1,744 \\
\hline May & 5.41 & 489 & 1,776 \\
\hline June & 5.15 & 456 & 1,656 \\
\hline July & 5.00 & 460 & 1,670 \\
\hline August & 5.40 & 494 & 1,793 \\
\hline September & 5.88 & 514 & 1,866 \\
\hline October & 5.37 & 485 & 1,760 \\
\hline November & 4.73 & 422 & 1,532 \\
\hline December & 5.38 & 499 & 1,811 \\
\hline Annual & 5.67 & 6,013 & 21,828 \\
\hline
\end{tabular}


The Table 3 shows the monthly solar radiation in $\mathrm{kWh} / \mathrm{m} 2 /$ day by a solar panel. By using this information, the energy generated by a solar panel of each rooftop by multiplying with the area of solar rooftop potential.

Energy generated per day $=$ area of solar potential* annual solar radiation

Energy generated per year $=$ area of solar potential $* 6,013$.

By using the above equation energy generated by each rooftop per year can be calculated easily.

\begin{tabular}{|c|c|}
\hline Requested Location & thirunagar chinnalapatti dindigul tamil nadu \\
\hline Weather Data Source & (IN) Gridded $10 \mathrm{~km}$ Satellite Data $4.5 \mathrm{~km}$ \\
\hline Latitude & $10.25^{\circ} \mathrm{N}$ \\
\hline Longitude & $77.95^{\circ} \mathrm{E}$ \\
\hline \multicolumn{2}{|c|}{ PV System Specifications (Residential) } \\
\hline DC System Size & $4 \mathrm{~kW}$ \\
\hline Module Type & Standard \\
\hline Array Type & Fixed (open rack) \\
\hline Array Tilt & $20^{\circ}$ \\
\hline Array Azimuth & $180^{\circ}$ \\
\hline System Losses & $14 \%$ \\
\hline Inverter Efficiency & $96 \%$ \\
\hline$D C$ to $A C$ Size Ratio & 1.1 \\
\hline
\end{tabular}

Table 4: Information about PV System Specification as Generated from the Internet

\subsection{AREA OF ROOFTOP}

The area of the solar potential rooftop can be calculated in ArcGIS by using the tool project in data management tools. This will calculate the area according to the digitized solar potential. The details of area of each rooftop are represented in map 4.2.

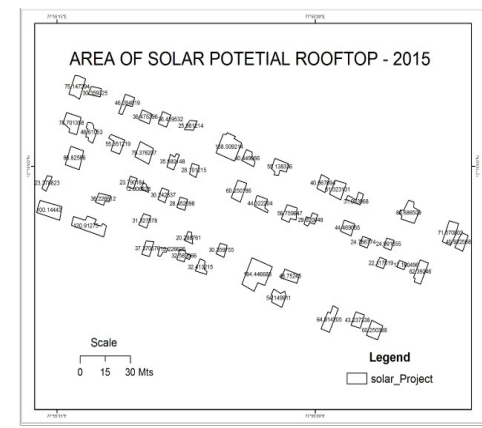

Map 3: Area of Solar Potential Rooftop - 2015 
Mechanical Engineering: An International Journal ( MEIJ), Vol. 3, No. 1, February 2016

Table 5. Area and Solar Radiation per Rooftop

\begin{tabular}{|r|r|r|r|}
\hline SI.No & $\begin{array}{c}\text { Area } \\
\text { (sq_m) }\end{array}$ & $\begin{array}{c}\text { Solar } \\
\text { radiation } \\
\text { kWh/day }\end{array}$ & $\begin{array}{c}\text { Solar } \\
\text { radiation } \\
\text { kWh/year }\end{array}$ \\
\hline 1 & 75.14 & 426.04 & 444828.80 \\
\hline 2 & 46.28 & 262.41 & 273977.60 \\
\hline 3 & 36.47 & 206.78 & 215902.40 \\
\hline 4 & 36.45 & 206.67 & 215784.00 \\
\hline 5 & 25.06 & 142.09 & 148355.20 \\
\hline 6 & 138.5 & 785.30 & 819920.00 \\
\hline 7 & 40.44 & 229.29 & 239404.80 \\
\hline 8 & 55.13 & 312.59 & 326369.60 \\
\hline 9 & 61.02 & 345.98 & 361238.40 \\
\hline 10 & 84.68 & 480.14 & 501305.60 \\
\hline 11 & 71.57 & 405.80 & 423694.40 \\
\hline 12 & 40.92 & 232.02 & 242246.40 \\
\hline 13 & 62.39 & 353.75 & 369348.80 \\
\hline 14 & 17.16 & 97.30 & 101587.20 \\
\hline 15 & 22.11 & 125.36 & 130891.20 \\
\hline 16 & 24.99 & 141.69 & 147940.80 \\
\hline 17 & 24.78 & 140.50 & 146697.60 \\
\hline 18 & 44.46 & 252.09 & 263203.20 \\
\hline 19 & 29.92 & 169.65 & 177126.40 \\
\hline 20 & 56.75 & 321.77 & 335960.00 \\
\hline 21 & 44.32 & 251.29 & 262374.40 \\
\hline 22 & 60.25 & 341.62 & 356680.00 \\
\hline 23 & 28.10 & 159.33 & 166352.00 \\
\hline 24 & 35.58 & 201.74 & 210633.60 \\
\hline 25 & 79.37 & 450.03 & 469870.40 \\
\hline 26 & 55.35 & 313.83 & 327672.00 \\
\hline 27 & 46.61 & 264.28 & 275931.20 \\
\hline 28 & 78.70 & 446.23 & 465904.00 \\
\hline 29 & 86.82 & 492.27 & 513974.40 \\
\hline 30 & 23.79 & 134.89 & 140836.80 \\
\hline 31 & 12.90 & 73.14 & 76368.00 \\
\hline 32 & 30.24 & 171.46 & 179020.80 \\
\hline 33 & 28.45 & 161.31 & 168424.00 \\
\hline 34 & 23.37 & 132.51 & 138350.40 \\
\hline 35 & 36.22 & 205.37 & 214422.40 \\
\hline 36 & 31.32 & 177.58 & 185414.40 \\
\hline 37 & 20.29 & 115.04 & 120116.80 \\
\hline & & & \\
\hline
\end{tabular}


Mechanical Engineering: An International Journal ( MEIJ), Vol. 3, No. 1, February 2016

\begin{tabular}{|r|r|r|r|}
38 & 30.35 & 172.08 & 179672.00 \\
\hline 39 & 184.44 & $1,045.77$ & 1091884.80 \\
\hline 40 & 48.75 & 276.41 & 288600.00 \\
\hline 41 & 54.14 & 306.97 & 320508.80 \\
\hline 42 & 64.91 & 368.04 & 384267.20 \\
\hline 43 & 43.23 & 245.11 & 255921.60 \\
\hline 44 & 60.25 & 341.62 & 356680.00 \\
\hline 45 & 100.14 & 567.79 & 592828.80 \\
\hline 46 & 120.91 & 685.56 & 715787.20 \\
\hline 47 & 37.37 & 211.89 & 221230.40 \\
\hline 48 & 32.58 & 184.73 & 192873.60 \\
\hline 49 & 32.41 & 183.76 & 191867.20 \\
\hline 50 & 15.22 & 86.30 & 90102.40 \\
\hline 51 & 30.35 & 172.08 & 179672.00 \\
\hline 52 & 31.08 & 176.22 & 183993.60 \\
\hline 53 & 40.86 & 231.68 & 241891.20 \\
\hline Total & $\mathbf{2 6 4 2 . 8 9}$ & $\mathbf{1 4 9 8 5 . 1 9}$ & $\mathbf{1 5 6 4 5 9 0 8 . 8 0}$ \\
\hline
\end{tabular}

The area of all the 53 rooftops is $2642 \mathrm{~m} 2$ and the total solar radiation received for a year is $15645908.80 \mathrm{kWh}$.

\subsection{FINDINGS}

The finding of this study shows that the total area of all the 53 rooftop that is potential for installing the solar panels are 2642.89 meter square, the energy produce per day by all the solar are $14,985.19 \mathrm{kWh}$, and for one year will be $1,56,45,908.80 \mathrm{kWh}$. The cost of the solar panel is Rs.75,000/- and Rs.90,000/- based on its efficiency.

\section{CONCLUSION}

This study has been carried out using Google Earth image and data from NREL online solar radiation calculator, considering the study area, since there is not much change in the climate condition compare with other region of the India, therefore, there is only few criteria to consider. This study describes about the importance of renewable energy in the fast growing population and demand for energy. So to solve this problem the best way is to bring solution that is friendly to the environment and also efficient in energy generation. The only way to bridge the gap between supply and demands is by means of using renewable energy. This study found out that has potential for installing solar panel. The rooftop were digitized and found out the area on the roof that has received maximum amount of sunlight by avoiding shade, shadow and type of roof. After using all these criteria the energy that can be generated from each rooftop has been calculated.

\section{REFERENCES}


Mechanical Engineering: An International Journal ( MEIJ), Vol. 3, No. 1, February 2016

[1] Dongrong Li A,Using Gis and Remote Sensing Techniques for Solar Panel Installation Site SelectionWaterloo, Ontario, Canada, 2013, p 7-10.

[2] Ashish kumar,Energy Statistic New Delhi 2015 p-12, 19 and 20.

[3] T.V. Ramachandran, Hotspots of Solar Potential in India, Banglore, 2011, p- 3181-83

[4] Taira Nakanishi, Identifying and Viewing Rooftop Solar Potential, California, 2010, p-27.

[5] Ha T. Nguyen, The Application of Lidar to Assessment of Rooftop Solar Photovoltaic Deployment Potential in a Municipal District Unit, 2012, p- 5-6.

[6] Bernd Resch,GüntherSagl, Tobias Törnros, Andreas Bachmaier, Jan-Bleicke Eggers, Sebastian Herkel, SattayaNarmsara and HartmutGündra,GIS-Based Planning and Modeling for Renewable Energy: Challenges and Future Research Avenues, p-669-671.

[7] "Statistical Review of World Energy 2015" (Pdf). Retrieved 17 June 2015.

[8] India Energy Profile Eia(Http://Www.Eia.Doe.Gov/Cabs/India/Full.Html)

[9] Brad Adam, Mapping Solar Energy Potential Through LiDAR Feature Extraction, USA, 2012, p-4.

[10] "Solar". Ministry of New and Renewable Energy, Govt. of India. Retrieved 21 February 2014.John G Van Hossain and Steven Letendre, Evaluating potential renewable energy resources in Poultney, Vermont: A GIS-based approach to supporting rural community energy planning, 2010 p-2019-20.

\section{Author}

Mani.N.D took M.Sc.Geography in 1979 and Ph.d in Perceptional Cartography in 1994. He is a Professor in the Department of Rural Development, the Gandhigram Rural Institute Deemed University since 1983 . He has successfully completed 32 research projects in the areas of digital cartography, application of Geographical Information System and remote sensing in natural resource management.

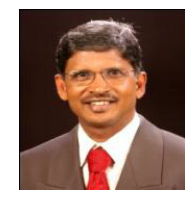

